\title{
Evaluation of polycyclic aromatic hydrocarbons (PAHs) in the corn drying process
}

\author{
Avaliação de hidrocarbonetos policíclicos aromáticos (HPAs) no processo de secagem do millho \\ Evaluación de hidrocarburos aromáticos policíclicos (HAPs) en el proceso de secado del maíz
}

Received: 10/28/2021 | Reviewed: 11/09/2021 | Accept: 12/06/2021| Published: 12/15/2021

\author{
ORCID: https://orcid.org/0000-0002-9181-1612 \\ Universidade Estadual do Oeste do Paraná, Brasil \\ E-mail: contato@jbm.agr.br \\ Reginaldo Ferreira Santos \\ ORCID: https://orcid.org/0000-0002-7745-9173 \\ Universidade Estadual do Oeste do Paraná, Brasil \\ E-mail: reginaldo.santos@unioeste.br \\ Gastón Merlet Venturelli \\ ORCID: https://orcid.org/0000-0003-2602-6471 \\ Universidad de Concepción, Chile \\ E-mail: reginaldo.santos@unioeste.br \\ Doglas Bassegio \\ ORCID: https://orcid.org/0000-0001-6628-8594 \\ Universidade Estadual do Oeste do Paraná, Brasil \\ E-mail: doglas.bassegio@unioeste.br \\ Silvia Renata Machado Coelho \\ ORCID: https://orcid.org/0000-0002-1614-8021 \\ Universidade Estadual do Oeste do Paraná, Brasil \\ E-mail: silvia.coelho@unioeste.br \\ Ana Paula Morais Mourão Simonetti \\ ORCID: https://orcid.org/0000-0002-0714-7799 \\ Centro Universitário Assis Gurgacz, Brasil \\ E-mail: anamourao@fag.edu.br \\ Telvi Marcelo Branco \\ ORCID: https://orcid.org/0000-0002-2544-0294 \\ Universidade Estadual do Oeste do Paraná, Brasil \\ E-mail: brancomarcelo@gmail.com \\ Karina Casanova Branco \\ ORCID: https://orcid.org/0000-0002-1059-8099 \\ Universidade Estadual do Oeste do Paraná, Brasil \\ E-mail: brancomarcelo@gmail.com
}

Joyce Bueno Mafra

\begin{abstract}
The pre-processing of agricultural products has great importance in the quality of the product, the most critical process, is the drying of grains, in which thermal energy is demanded. Since biomass burning produces polycyclic aromatic hydrocarbons (PAHs), which can be associated with carcinogenesis The objective of this study was to perform an assessment of the presence of PAHs derived from the maize drying process using Cavaco burning as a fuel source. The experiment was conducted in the municipality of Cascavel-Paraná, in a storage unit located in Colônia Melissa, using a Kepler Weber column dryer model ADS 150, with a capacity of $150 \mathrm{t} / \mathrm{h}$, with an IMTAB chip burner, with capacity of $8,000,000 \mathrm{kcal} / \mathrm{h}$. To assess the presence of PAHs, corn samples were collected at the entry of the product into the storage unit (control) and samples were collected after the drying process with two passes in the dryer, for five days, every hour during eight hours a day, in the period of harvest/2020. All results obtained were below the detectable limit of $0.6 \mu \mathrm{g} / \mathrm{kg}$. It is concluded with this study that the drying process of corn using chips in burners does not significantly produce PAHs, thus not harming the quality of the grain.
\end{abstract}

Keywords: Biomass energy; Thermal energy; Column dryer; Carcinogenesis.

\section{Resumo}

O pré-processamento de produtos agrícolas tem grande importância na qualidade do produto. O processo mais crítico, é a secagem dos grãos, no qual é demandada energia térmica. Como a queima da biomassa produz hidrocarbonetos policíclicos aromáticos (HPAs), que podem estar associados à carcinogênese. O objetivo deste trabalho foi avaliar a presença de HPAs derivados do processo de secagem do milho utilizando a queima do Cavaco como combustível. O experimento foi conduzido no município de Cascavel-Paraná, em uma unidade de armazenamento localizada na Colônia Melissa, utilizando um secador de coluna Kepler Weber modelo ADS 150, com capacidade de 150t/ h, com queimador de cavacos IMTAB, com capacidade de $8.000 .000 \mathrm{kcal} / \mathrm{h}$. Para avaliar a presença de HAPs, foram 
coletadas amostras de milho na entrada do produto na unidade de armazenamento (controle) e após o processo de secagem com duas passagens no secador, por cinco dias, a cada hora durante oito horas diárias. , no período de safra / 2020. Todos os resultados obtidos ficaram abaixo do limite detectável de $0,6 \mu \mathrm{g} / \mathrm{kg}$. Conclui-se com este estudo que o processo de secagem do milho com cavacos em queimadores não produz HAPs significativamente, não prejudicando a qualidade do grão.

Palavras-chave: Energia de biomassa; Energia térmica; Secador de coluna; Carcinogênese.

\section{Resumen}

El preprocesamiento de productos agrícolas tiene gran importancia en la calidad del producto, el proceso más crítico, es el secado de granos, en el que se demanda energía térmica. Dado que la quema de biomasa produce hidrocarburos aromáticos policíclicos (HAP), que pueden estar asociados con la carcinogénesis, el objetivo de este estudio fue realizar una evaluación de la presencia de HAP derivados del proceso de secado del maíz utilizando la combustión de Cavaco como fuente de combustible. El experimento se realizó en el municipio de Cascavel-Paraná, en una unidad de almacenamiento ubicada en Colônia Melissa, utilizando un secador de columna Kepler Weber modelo ADS 150, con una capacidad de $150 \mathrm{t} / \mathrm{h}$, con un quemador de chips IMTAB, con capacidad de 8.000.000 kcal. / h. Para evaluar la presencia de HAP, se recolectaron muestras de maíz al ingreso del producto a la unidad de almacenamiento (control) y se recolectaron muestras luego del proceso de secado con dos pasadas en el secador, durante cinco días, cada hora durante ocho horas al día, en el período de cosecha / 2020. Todos los resultados obtenidos estuvieron por debajo del límite detectable de $0,6 \mu \mathrm{g} / \mathrm{kg}$. Se concluye con este estudio que el proceso de secado del maíz utilizando chips en quemadores no produce significativamente HAP, por lo que no daña la calidad del grano.

Palabras clave: Energía de biomasa; Energía térmica; Secador de columna; Carcinogénesis.

\section{Introduction}

Over the past few decades, corn has reached the level of the largest agricultural crop in the world, being the only one to have surpassed the 1 billion ton mark, applied to various uses in world production, estimates point to more than 3,500 applications of this cereal (EMBRAPA, 2019).

In order to comply with the agricultural calendar and maintain the quality of corn grains in the post-harvest period, the ideal moisture content must be between 12 and $13 \%$ bu, with a maximum tolerance of $14 \%$ bu, when the technique is correctly applied. of aeration in storage (Queiroz et al., 1987).

Currently, the most widespread system in the pre-processing of grains and seeds is drying, which converts energy from biomass (fuel) into thermal energy, by burning wood in furnaces, in which the heated air is sent to the dryer grains (Brooker et al., 1992).

A market trend is the automation of production systems, in the drying process automation has been carried out through the use of chips that are burned in burners, this method allows the burner to be fed by conveyors, thus increasing control levels temperature of the drying system, thus eliminating manual labor in feeding the furnace.

The dryers on the market have a high level of technology, such as: automatic control of the air mixing system, moisture meters of the product flowing in the dryer and control panels that allow control of the entire drying process (Souza et al., 2002). Temperature and drying time are the main variables that affect the quality of the process and the product, it is essential that the temperature of the grain mass is kept within safe limits recommended by CONAB (Villela et al., 1997). During the biomass burning process, a wide variety of compounds are produced, ranging from the best known ones, such as carbon monoxide and carbon dioxide, to unidentified compounds, among this variety of compounds produced during pyrolysis. PAHs are a class of compounds that result from the incomplete combustion of heating organic matter and their main characteristic is the presence of two or more benzene rings condensed in a structure (Swallow, 1976).

PAHs originate in the process of pyrolysis and pyrosynthesis, both the quantity and composition of the PAHs produced depend on the material to be pyrolyzed, the combustion temperature, the residence time of the molecules in the gaseous state and of the oxygen concentration. During the pyrolysis and pyrosynthesis process, both the quantity and composition of the PAHs produced vary depending on the material to be pyrolyzed, the combustion temperature, the time the molecules remain in the gaseous state and the oxygen concentration. The formation of these compounds is favored mainly at 
temperatures between 400 and $800^{\circ} \mathrm{C}$. When the temperature varies from 400 to $500^{\circ} \mathrm{C}$, the formation of hydrocarbons with low molar mass (128-202) is observed, such as naphthalene, acenaphthalene, fluorene, phenanthrene, anthracene, fluoranthrene and pyrene. However, at temperatures equal to or greater than $500^{\circ} \mathrm{C}$, the formation of hydrocarbons with a molar mass between 228-252 is observed, such as chrysene, benzene(a) anthracene and benzo(a)pyrene (Williams \& Horne, 1995; Mcgrath et al., 2003).

Contamination of food by PAHs can occur in two ways: through deposition of these compounds from the air or water, due to precipitation, or through drying and cooking (Zebek, 1980; Lawrence \& Weber, 1984; Yang et al., 1998 ; Camargo \& Toledo, 2003) observed that lettuce samples cultivated close to highways, that is, subject to pollution, presented total PAH values of $1.67-2.40 \mu \mathrm{g} / \mathrm{kg}$, values higher than those found in samples cultivated in interior regions from 0.84 to $1.27 \mu \mathrm{g} / \mathrm{kg}$.

In Brazil there is only legislation for water determined by Resolution RDC $n^{\circ} 274 / 2005$ which establishes the limit of $0.7 \mu \mathrm{g} / \mathrm{L}$ and for foods that have added smoke aromas according to Resolution RDC ${ }^{\circ}$ 2/2007 limiting it to less than $0.03 \mathrm{ppb}$ (BRASIL, 2005).

There is great interest in the scientific world of these hydrocarbons due to their high carcinogenic and mutagenic potential (Menzie et al., 1992). They constitute a family of compounds that are characterized by having two or more condensed aromatic rings and that can be divided into two classes: compounds with low molecular mass (MM), with $\mathrm{MM}<202$.

The study hypothesis was that indirect burning does not transmit polyclinic aromatic hydrocarbon residues to the grain mass. Thus, the objective of this work was to evaluate the presence of PAHs in corn resulting from the drying process.

\section{Methodology}

The experiment was carried out in a storage unit of a cooperative in the municipality of Cascavel, Paraná, Brazil. The experiment was carried out during the 2020 corn crop in August, from 08/08 to 28/08, being collected 5 days: 08/08; 11/08; $12 / 08 ; 27 / 08$; and $08 / 28$ for 8 hours, the entire drying process was followed.

Table 1 shows the mean values during the 5 days of the experiment of corn moisture at the entrance, at the exit moisture from dryer 1 and at the exit humidity at dryer 2.

Table 1. Data of average inlet and outlet humidity of dryers.

\begin{tabular}{ccccc}
\hline \multicolumn{5}{c}{ Daily averages data } \\
\hline Days & Inlet U (\%) & $(\%)$ Outlet 1st Dryer U & U (\%) Outlet 2nd Dryer \\
\hline 1st Day & $08 / 08 / 2020$ & 21.7 & 17.3 & 13.8 \\
2and Day & $11 / 08 / 2020$ & 22.5 & 17.7 & 13.8 \\
3rd Day & $12 / 08 / 2020$ & 22.5 & 16.8 & 13.9 \\
4th Day & $27 / 08 / 2020$ & 24.3 & 17.0 & 13.8 \\
5th Day & $28 / 08 / 2020$ & 22.8 & 17.3 & 14.0 \\
\hline
\end{tabular}

Source: Authors.

The same values were obtained directly, through hourly/hour sampling during the 8-hour drying period. It was observed that taking into account the general averages, the product was received in the storage unit with an average of $22.5 \%$ moisture. In the first pass in dryer 1, the average humidity was $17.3 \%$ and at the exit of dryer 2 , the average humidity was $13.8 \%$ (Table 1).

A column dryer brand Kepler Weber, model ADS 150, with a capacity of $150 \mathrm{t} / \mathrm{h}$ was used. Controlled drying air temperature between 80 and $90^{\circ} \mathrm{C}$, to meet industrial product quality parameters. The drying system is composed of a dryer of 
$8,000,000 \mathrm{kcal} / \mathrm{h}$. The grain used will be corn (Zea mays L.) which belongs to the Gramineae/Poaceae family with an initial moisture content of approximately $24 \%$ b.u. To measure the internal temperature of the dryer, a digital electronic thermometer, brand WIDITEC, model TERMOSEC KT-4 was used. For this reason during the collection of each hourly sample.

For analysis and comparison of the data, samples were collected at the reception (Scale) of the unit (control samples) and samples at the foot of the dryer (treatment samples). Collecting $1 \mathrm{~kg}$ samples every hour for 8 hours a day. At the end of the day, the samples were homogenized in a splitter, resulting in 1 sample of $4 \mathrm{~kg} / \mathrm{day}$. The samples were kept cooled to $18^{\circ} \mathrm{C}$. Samples were analyzed using the same methodology as AOAC 20th edition/CR -0007;

As on average the product arrived at the unit with $22.5 \%$ moisture, for storage the product went through the drying process twice, reaching an average of $17.3 \%$ moisture with 1 pass, and with 2 passes reaching an average of $13.8 \%$ humidity, according to $\mathrm{CONAB}$ recommendations. Therefore, the samples collected for analysis were those that passed twice through the dryer. Between passes through the dryer, the product moisture was checked with a MEDITEC brand moisture meter. The unit where the study was carried out has 2 Kepler Weber model ADS dryers with a capacity of $150 \mathrm{t} / \mathrm{h}$. Thus, the 1 st pass was made through dryer 1 and the second pass through dryer 2, thus optimizing the logistics of the process. After the product is dry, it goes to storage and the result of each day of collection was $8 \mathrm{~kg} / \mathrm{day}$.

The unit's dryers are fed by IMTAB brand chip burners model Hercules with a capacity of 8,000,000 kcal/h (Figure 1).

Figure 1. IMTAB Chip Burner.

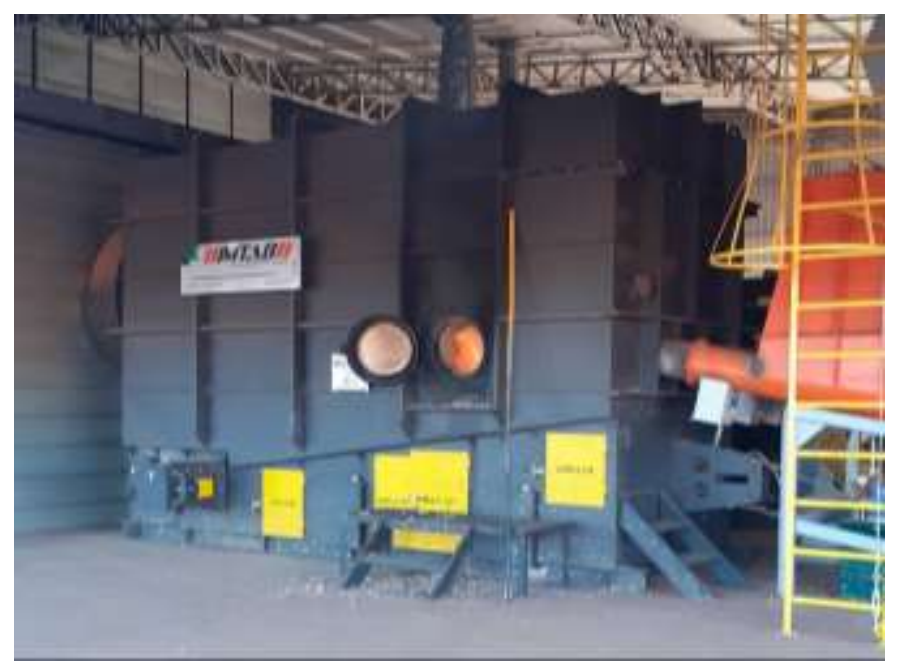

Source: Authors.

The burner is fed by (fuel) chips by automated conveyors that allow temperature control in the dryers, which work at temperatures from 90 to $100^{\circ} \mathrm{C}$. The chip used in the unit comes from Eucalyptus with a particle size of $3 \mathrm{~cm}-5 \mathrm{~cm}$ with $20 \%$ humidity, which is stored in a covered area in the unit.

Drying temperature, ambient temperature in the storage unit, relative humidity of the ambient air, humidity at the entrance and exit of the grains in the storage unit and PAHs were evaluated.

\section{Results and Discussion}

The present work had as expected result, the scientific proof of the absence or not of PAHs in corn grains after the drying process. The hypothesis raised was that the indirect burning process by means of chip burners provides better fuel energy yield with its complete burning and, as it does not emit smoke residues for the grains in the dryer, it avoids 
contamination by PAHs. This results in better chemical and physical quality and meets legal requirements for export, optimizing the quality of processed foods, avoiding possible carcinogenic changes in animal cells. The results of PAHs obtained in this study by the Laboratory Center for Analytical Quality - CQA were lower than the detection limit, which is 0.6 $\mu \mathrm{g} / \mathrm{kg}$. The presence of 16 PAHs were analyzed: Acenaphthene; Acenaphthylene;Anthracene;Benzo(a)anthracene; benzo(a)fluoranthene; Benzo(a)pyrene; Benzo(b)fluoranthene; Chrysene; Dibenzo(a,h)anthracene; Phenanthrene; Fluorene; In(1,2,3-c,d)pyrene; Naphthalene; Pyrene and total PAHs, which are the main compounds studied. Among these 16 compounds the most dangerous to health are the Benzenes.

According to European regulation 835/2011, the maximum allowed level for the sum of the four compounds, fluoranthene, pyrene, benzo(a) anthracene and chrysene is $1.0 \mu \mathrm{g} / \mathrm{kg}$ for processed cereal-based foods, but none maximum level is set for corn kernels. The values determined in this study are higher than the maximum limit established by the European Union for processed cereal-based foods. According to Cardoso et al. (2010), carbonization of eucalyptus wood in a kiln is mostly between 400 and $500{ }^{\circ} \mathrm{C}$. Therefore, it can be suggested that drying the grain with wood favors the production of low molecular weight PAHs, which is consistent with the results obtained by Lima et al., 2017, where more than $85 \%$ of PAHs were of low weight molecular.

According to Cardoso et al. (2010), carbonization of eucalyptus wood in a kiln is mostly between 400 and $500{ }^{\circ} \mathrm{C}$. Therefore, it can be suggested that drying the grain with wood favors the production of low molecular weight PAHs, which is consistent with the results obtained by Lima et al. (2017), where more than 85\% of PAHs were of low weight molecular.

Escarrone et al. (2014) observed values in the order of 1-7 $\mu \mathrm{g} / \mathrm{kg}$ for fluoranthene and naphthalene, respectively, in white rice and parboiled rice. The authors did not justify the fact that grains dried with LPG (liquefied petroleum gas) had higher concentrations than grains dried with wood. The difference in concentrations between this study and that of Escarrone et al. (2014) can be attributed to the fact that rice grains, unlike corn, have a husk that prevents contamination.

In the present study, benzo(a)pyrene was not detected, which is in agreement with the results of Lima et al. (2017), Houessou et al. (2007), who did not find significant amounts of benzo(a)pyrene in roasted coffee beans, even at high temperatures. Furthermore, Stanciu et al. (2008), Lee and Shin (2010) and Tfouni et al. (2012) report low levels of this compound in roasted coffee, without justifying it. However, Wandan et al. (2011) found benzo(a) pyrene, ranging from 0 to $3701 \mu \mathrm{g} / \mathrm{kg}$, when cocoa beans were sun-dried or subjected to contact with smoke for 8 days. This presence may be related to long-term exposure to smoke, which did not happen in the present study.

Different concentrations found in the cited articles are examples that the presence of PAHs depends on the type of fuel, drying time, drying process (with or without contact with smoke), type of grain, among other factors.

In the European Community, the Scientific Committee for Food has established permitted limits for four substances. Table 2 shows maximum values for some foods, but there is no recommendation for maximum allowable levels of PAHs in grains. The closest product with maximum allowable levels of PAHs are processed cereal-based foods. 
Table 2. Maximum allowable levels of PAHs in food, according to the European Union.

\begin{tabular}{|c|c|c|}
\hline \multirow[b]{2}{*}{ Foods } & \multicolumn{2}{|c|}{ Maximum Content $(\mu \mathrm{g} / \mathrm{kg})$} \\
\hline & $\begin{array}{l}\text { Benzo (a) } \\
\text { pireno }\end{array}$ & $\begin{array}{l}\text { Benzo (a) pireno + benzo (a) } \\
\text { antraceno + benzo (b) } \\
\text { fluoranteno + criseno }\end{array}$ \\
\hline $\begin{array}{l}\text { Oils and fats (except cocoa butter and coconut oil) } \\
\text { intended for human consumption or use as food } \\
\text { ingredient }\end{array}$ & $2.0 \mu \mathrm{g} / \mathrm{kg}$ & $10.0 \mu \mathrm{g} / \mathrm{kg}$ \\
\hline Cocoa beans and derivatives products & $5.0 \mu \mathrm{g} / \mathrm{kg}$ & $\begin{array}{l}35.0 \mu \mathrm{g} / \mathrm{kg} \text { and } \\
\quad 30 \mu \mathrm{g} / \mathrm{kg}\end{array}$ \\
\hline Coconut oil & $2.0 \mu \mathrm{g} / \mathrm{kg}$ & $20.0 \mu \mathrm{g} / \mathrm{kg}$ \\
\hline Bivalve molluscs (smoked) & $6.0 \mu \mathrm{g} / \mathrm{kg}$ & $35.0 \mu \mathrm{g} / \mathrm{kg}$ \\
\hline $\begin{array}{l}\text { Cereal-based processed foods and foods for babies and } \\
\text { young children }\end{array}$ & $1.0 \mu \mathrm{g} / \mathrm{kg}$ & $1.0 \mu \mathrm{g} / \mathrm{kg}$ \\
\hline
\end{tabular}

Source: Adapted from: Official Journal of the European Union of 20/08/2011 (CEC, 2011).

Table 3 shows the amounts of benzo(a) anthracene and chrysene determined in the study by Lima et al. (2017), who worked with direct heat drying in corn. Comparing these values with those in Table 3 , we can see that they are higher than the maximum level defined by European Union regulations for cereal-based foods.

Table 3. Benzo (a) anthracene and chrysene present in maize grains after drying with firewood.

\begin{tabular}{lccc}
\hline \multirow{2}{*}{ Compound } & \multicolumn{3}{c}{ PAHs $(\mu \mathrm{g} / \mathrm{kg})$} \\
\cline { 2 - 4 } & $60^{\circ} \mathrm{C}$ & $60^{\circ} \mathrm{C} / 80^{\circ} \mathrm{C}$ & $80^{\circ} \mathrm{C}$ \\
\hline Benzo (a) antraceno & 6.89 & 7.13 & 7.25 \\
Crisene & 6.18 & 6.79 & 7.02 \\
$\Sigma$ & 13.07 & 13.92 & 14.27 \\
\hline
\end{tabular}

Source: Adapted from Lima et al. (2017).

In Brazil, hot air supply for dry grains is accomplished by fuel combustion in countercurrent flow ovens, however combustion in these ovens is generally incomplete with carbon monoxide emissions and particulate materials such as PAHs, thus compromising grain quality. Factors that contribute to the generation of these unwanted products in this type of combustion are associated with inadequate operation, especially the use of green or wet wood, or lack of regularity in the supply of the combustion chamber, resulting in excessive air velocity in the furnace and the incomplete combustion, contributing to the high degree of contamination (Klautau, 2008).

The presence of PAHs in foods, industrialized or not, is mainly due to their formation during certain types of processing such as smoking, roasting and direct drying with wood. Therefore, PAHs can be found in different foods, such as vegetable oils, margarines, mayonnaise, dairy products, fruits, vegetables, smoked products, tea, yerba mate, coffee, sugar, cereals, water, seafood, grilled foods, beverages (Tfouni et al., 2007; Galinaro \& Franco, 2009; Orecchio et al., 2009; Lee \& Shin, 2010; Wretling et al., 2010; Silva et al., 2015).

According to Camargo and Toledo (2000), the control of drying by industry is complex, since many variables are involved in greater or lesser contamination by PAHs, such as the type of wood used for burning, the grain size and the presence of residues. 
Therefore, the presence of PAHs in corn kernels dried with indirect fire were not found at significant levels in this study, thus reducing the risks of contamination of the kernels during drying. This study demonstrates an advance in research in this area, highlighting the importance for Brazil to adopt legislation to establish maximum levels allowed for food.

\section{Conclusion}

Both the control samples that did not go through the drying process, and the samples that went through the drying process, regardless of climatic conditions and drying time, did not show contamination by PAHs. It is a positive point for the agro-industry and its technological innovation in grain drying.

Drying with wood as fuel depends on the exposure time of the product to be dried. Expanding research in this area with different types of drying ovens to regulate the maximum permitted levels of PAHs in grain is highly recommended.

\section{References}

Brasil. (2005). Ministério Da Saúde. Ministério Da Saúde Agência Nacional De Vigilância Sanitária. Brasilia.

Brooker, D. B., Bakker-Arkema, F. W., \& Hall, C. W. (1992). Drying and storage of grains and oilseeds. Springer Science \& Business Media.

Camargo, M. S. F. O., \& Toledo, M. (2000). Hidrocarbonetos aromáticos policíclicos em margarina, creme vegetal e maionese. Food Science and Technology, 20, 51-55.

Camargo, M. C. R., \& Toledo, M. C. F. (2003). Polycyclic aromatic hydrocarbons in Brazilian vegetables and fruits. Food control, $14(1)$, $49-53$.

Cardoso, M. T., Carneiro, A. C. O., Damásio, R. A. P., Jacovine, L. A. G., Vital, B. R., Martins, M. C., \& Santos, R. C. (2010). Effect of combustion carbonization gases on the gravimetric yield of Eucalyptus sp wood. Ciência da Madeira, 1(2), 20-31.

CEC - Commission Of The European Communities. Commission Regulation (EC) (2011) Setting of maximum levels for certain contaminants in foodstuffs. Regulation, (1881), 5-24.

Embrapa - Empresa Brasileira De Pesquisa Agropecuária. (2019). Jornal Eletrônico Da Embrapa Milho E Sorgo. 106. Http://Grao.Cnpms.Embrapa.Br/Noticia.Php?Ed=Nzg=\&Id=Mza3.

Escarrone, A. L. V., Caldas, S. S., Furlong, E. B., Meneghetti, V. L., Fagundes, C. A. A., Arias, J. L. O., \& Primel, E. G. (2014). Polycyclic aromatic hydrocarbons in rice grain dried by different processes: Evaluation of a quick, easy, cheap, effective, rugged and safe extraction method. Food chemistry, 146, 597-602.

Galinaro, C. A., \& Franco, D. W. (2009). Polycyclic aromatic hydrocarbons (PAHS) in cachaça, rum, whiskey and alcohol fuel. Química nova, 32(6), 14471451 .

Houessou, J. K., Maloug, S., Leveque, A. S., Delteil, C., Heyd, B., \& Camel, V. (2007). Effect of roasting conditions on the polycyclic aromatic hydrocarbon content in ground Arabica coffee and coffee brew. Journal of agricultural and food chemistry, 55(23), 9719-9726.

Klautau, J. V. P. (2008). Análise experimental de uma fornalha a lenha de fluxo co-corrente para secagem de grăos. Curitiba.

Lee, K., \& Shin, H. S. (2010). Determination of polycyclic aromatic hydrocarbons in commercial roasted coffee beans. Food Science and Biotechnology, 19(6), 1435-1440.

Lawrence, J. F., \& Weber, D. F. (1984). Determination of polycyclic aromatic hydrocarbons in Canadian samples of processed vegetable and dairy products by liquid chromatography with fluorescence detection. Journal of Agricultural and Food Chemistry, 32(4), $794-797$.

Lima, R. F., Dionello, R. G., Peralba, M. D. C. R., Barrionuevo, S., Radunz, L. L., \& Júnior, F. W. R. (2017). PAHs in corn grains submitted to drying with firewood. Food chemistry, 215, 165-170.

McGrath, T. E., Chan, W. G., \& Hajaligol, M. R. (2003). Low temperature mechanism for the formation of polycyclic aromatic hydrocarbons from the pyrolysis of cellulose. Journal of Analytical and Applied Pyrolysis, 66(1-2), 51-70.

Menzie, C. A., Potocki, B. B., \& Santodonato, J. (1992). Exposure to carcinogenic PAHs in the environment. Environmental science \& technology, 26(7), $1278-1284$.

Orecchio, S., Ciotti, V. P., \& Culotta, L. (2009). Polycyclic aromatic hydrocarbons (PAHs) in coffee brew samples: analytical method by GC-MS, profile, levels and sources. Food and Chemical Toxicology, 47(4), 819-826.

Queiroz, D., Pereira, J., \& Melo, E. Determinação de vazões mínimas de ar para secagem de milho em baixas temperaturas na região de Viçosa, Minas Gerais. Revista Brasileira de Armazenamento, 11, 1-12.

Souza, C. M. A. D., Queiroz, D. M. D., \& Lacerda Filho, A. F. D. (2002). Simulação do processo de secagem de sementes de milho em camada fixa. Scientia Agricola, 59, 653-660. 
Research, Society and Development, v. 10, n. 16, e403101622444, 2021

(CC BY 4.0) | ISSN 2525-3409 | DOI: http://dx.doi.org/10.33448/rsd-v10i16.2444

Stanciu, G., Dobrinas, S., Birghila, S., \& Popescu, M. (2008). Determination of organic compounds from different types of coffee by hplc and gc-ecd analysis. Environmental Engineering \& Management Journal, 7(6).

Swallow, W. H., \& WH, S. (1976). Survey of polycyclic aromatic hydrocarbons in selected foods and food additives available in New Zealand. New Zealand Journal of Science, 19, 407-412.

Tfouni, S. A. V., Vitorino, S. H. P., \& Toledo, M. C. D. F. (2007). Efeito do processamento na contaminação de cana-de-açúcar e derivados por hidrocarbonetos policíclicos aromáticos. Food Science and Technology, 27, 76-82.

Tfouni, S. A., Serrate, C. S., Carreiro, L. B., Camargo, M. C., Teles, C. R., Cipolli, K. M., \& Furlani, R. P. (2012). Effect of roasting on chlorogenic acids, caffeine and polycyclic aromatic hydrocarbons levels in two Coffea cultivars: Coffea arabica cv. Catuaí Amarelo IAC-62 and Coffea canephora cv. Apoatã IAC-2258. International Journal of Food Science \& Technology, 47(2), 406-415.

Villela, F. A., \& Peske, S. T. (1997). Tecnologia pós-colheita para arroz. Peske, ST; Nedel, JL; Barros, ACSA Produção de arroz irrigado. Pelotas: UFPel, $351-412$.

Wandan, E. N., Elleingand, E. F., \& Ndouba, A. M. (2011). A screening for benzo [a] pyrène in cocoa beans subjected to different drying methods during on farm processing. International Journal of Engineering, Science and Technology, 3, 3621-3630.

Williams, P. T., \& Horne, P. A. (1995). Analysis of aromatic hydrocarbons in pyrolytic oil derived from biomass. Journal of Analytical and Applied pyrolysis, $31,15-37$.

Wretling, 1. S., Eriksson, A., Eskhult, G. A., \& Larsson, B. (2010). Polycyclic aromatic hydrocarbons (PAHs) in Swedish smoked meat and fish. Journal of food composition and analysis, 23(3), 264-272.

Yang, H. H., Lee, W. J., Chen, S. J., \& Lai, S. O. (1998). PAH emission from various industrial stacks. Journal of Hazardous materials, 60(2), $159-174$.

Zebek, M. S. (1980). Polycyclic aromatic hydrocarbon': A review. Journal of Environmental Pathology, Toxicology and Oncology, 3 , $537-567$. 